\title{
Tragedy and the Tragic: A Study of Ernst Hemingway's A Farewell to Arms and Naguib Mahfouz's The Beginning and the End
}

\author{
Rania Khelifa Chelihi ${ }^{1}$, Mohd Nazri Latiff Azmi ${ }^{1}$, Hardev Kaur ${ }^{2} \&$ Ayaicha Somia ${ }^{2}$ \\ 1 Faculty of languages and communications, Department of English language, UNISZA, 21300 Kuala \\ Terengganu, Terengganu, Malaysia \\ ${ }^{2}$ Department of Language and Humanities Education, Universiti Putra Malaysia, Putrajaya, $\cdot$ Malaysia \\ Correspondence: Rania Khelifa Chelihi, Faculty of languages and communications, Department of English \\ language, UNISZA, 21300 Kuala Terengganu, Terengganu, Malaysia. E-mail: rania.shelihi@gmail.com
}

Received: May 23, 2018 Accepted: June 20, 2018 Online Published: November 27, 2018

doi:10.5539/ijel.v8n7p7 URL: https://doi.org/10.5539/ijel.v8n7p7

\begin{abstract}
This paper is a comparative study between Ernst Hemingway's A Farewell to Arms and Naguib Mahfouz's The Beginning and the End, paralleled with the authors' concepts of tragic vision; based on the development of the theory of tragedy from Aristotle to Hegel as well as the personal philosophy of life as tragedy of both authors. Based on the researcher knowledge, tragedy concept in the selected novels is rarely and insufficiently highlighted by few scholars and critics. Moreover, it is a comparison of novels from different cultures-Arabic literature and literature in English - in order to bridge the gap between them. The novels are stories where every day moral dilemmas often present profound paradoxes with which heroes and heroines must deal. Tragedy, in the same vein, is such a paradoxical story where we have to deal at any rate with our everyday moral dilemmas, where we are sometimes called upon to make difficult choices not between right and wrong, but between what we might define as two rights. Hegelian concept of tragedy focused on dissension and war of dichotomies between good and bad, as well as what is right and what is wrong. The tragic elements in the two novels make them Hegelian tragedies par excellence.
\end{abstract}

Keywords: tragedy, the tragic, the theory of tragedy, Ernst Hemingway, Naguib Mahfouz, personal philosophy of life

\section{Introduction}

Tragedy plays a crucial role in both Hegel's Phenomenology of Mind and his lectures on the "Philosophy of History." According to Bushnell: "For Hegel, tragedy is the conflict of two substantive positions... [It] can be resolved only with the fall of the hero... Hegelian tragedy is the conflict of two goods" (2005). In the opinion of Hegel, the most arresting type of conflict in ancient tragedy is that which deals with the politic, that is, with "the opposition between ethical life in its social universality and the family as the natural ground of moral relations" (Memmott, 2004). Second, Antigone, in the Lectures on the Philosophy of Religion, is mentioned in the clearest embodiment of the divine forces of family and community life: "The collision between the two highest moral powers is set forth in a plastic fashion in that supreme and absolute example of tragedy, Antigone." Finally, it is also mentioned in The Philosophy of Fine Arts on opposition between these divine powers, Hegel once again isolates the Antigone as "one of the most sublime, and in every respect most consummate works of art human efforts ever produced" (McDonald, 2003). Further, Hegel's theory of life and art explains that 'art is similar to life,' and this so applicable to Mahfouz and Hemingway as well. To conclude, Hegel's theory on the tragic helps us to a great extent analyze the tragic conflict in this plays. He focuses on the tragic vis-à-vis tragedy. And for me, Hegel is the best whom can we depend upon analyzing Shakespeare's Othello. Not only that but also he uses other supportive techniques of increasing the tragic conflict.

\section{Tragic Vision in Hemingway's $A$ Farewell to Arms}

The very beginning of $A$ Farewell to Arms expresses Hemingway's tragic idea of the heart-rending human life in this world. Non-humans share humans their suffering and appearance in the novel; a point that is technically made clear in points of view through descriptive passages of natural scenery before war and during war. This way of depiction in fiction is aesthetically made by the author's intervention. Fredrick artistically describes the 
scenery while moving with his unit to Gorizia: "The forest of oak trees on the mountain beyond the town was gone. The forest had been green in the summer when we had come into the town but now there were the stumps and the broken trunks and the ground torn up..." (Hemingway, 1935). This is the world we have in Hemingway's A Farewell to Arms; a world where on the human level seven thousand died of cholera, where men are villains as they carry not life but death that is symbolized by weapons, a world void of moral standards, a world where "We first meet our hero in a brothel." (Note 1) (ibid) Whereas on the non-human level, particularly flora. Here, it is important to note that Hemingway relies a good deal, as we see in the previous passage, on human and non-human imagery for achieving tragic effects in his prose style. What Scott Donaldson said about the opening of A Farewell to Arms is also applicable to the other descriptive passages in the novel that they "must be read like poetry, as encoded language whose implicit message will only yield itself to a painstaking cryptographer." (qtd. in Bhim S. Dahiya's Hemingway's A Farewell To Arms: A Critical Study, 1992). It seems that Hemingway's novel, A Farewell to Arms, was crafted from his earliest experience with war. As a teenager just out of high school, Hemingway volunteered to fight in the First World War but was rejected because of poor eyesight. Instead, he drove a Red Cross ambulance on the Italian front, where he was wounded in 1918 by a mortar shell. His own story in the hospital falling in love with Agnes von Kurowsky, his senior is depicted in this novel through the story of Catherine and Frederick, though the latter differs somehow from Hemingway's. Hemingway, to some extent, fictionalized his story in A Farewell to Arms. Lieutenant Frederick Henry meets Catherine Barkley in a small town near the Italian Alps. Catherine is still mourning the death of her ex-fiancé, who was a victim of the war, however, both Frederick in a way attracts her. After that, Frederick is injured and is taken to the hospital. The hospital becomes the best setting of strengthening and deepening the love affair between them. The love affair leads, then, to Catherine's pregnancy; a news that is a source of happiness and dread for the couple. Though the couple has escaped the war, there are dangers that cannot be anticipated or avoided. This way the story of the couple turns out to be heartbreaking and tragic masterpiece in modern literature.

The tragic appeal of $A$ Farewell to Arms does not lie simply in its plot. Rather, it is Hemingway's writing style that transforms the story into a great tragedy. The critic Cowley considered it "one of the few Great War stories in American literature" (1990). He once described his method this way: "I always try to write on the principle of the iceberg. There is seven-eighths of it under water for every part that shows. Anything you know you can eliminate and it only strengthens your iceberg" (ibid).

According to Merrill, “A Farewell to Arms is probably Hemingway's most admired novel, but few critics have taken seriously his suggestion that the book is a tragedy." (Note 2) Here, the point to be made is unveiling the obscurity of Hemingway's contribution to tragedy as a literary form; a point that is rarely and insufficiently highlighted by few scholars and critics. Needless to say that Hemingway had no objection to conceiving his work as a tragedy, hence, it is left to the reader to explore more about this issue on the light of the previously mentioned hints on tragedy and the tragic. However, Hemingway himself notes that "The fact that the book was a tragic one did not make me unhappy since I believed that life was a tragedy and knew it could only have one end." (Note 3). Merrill in this regard affirms that "Hemingway has fashioned a new form of ... The belief that life is a tragedy, life itself, has become the backbone for a new literary structure" (2014).

The position occupied by A Farewell to Arms among Hemingway's tragic works, according to Bloom, "may be suggested by the fact that he once referred to the story of Lieutenant Frederic Henry and Catherine Barkley as his Romeo and Juliet" (1987). Catherine in A Farewell to Arms is "a good woman caught up in a tragic world that does not reward her virtue" (ibid). Although she is able to elope with Frederick, she never does that. Nature also plays a central role in preparation for the couple's tragedy. The appearance of a plain "rich with corps" along with rain at the outset of the novel serves as a symbol of death later. The narrator reports that "In the fall when the rains came the leaves all fell from the chestnut trees and the branches were bare and the trunks black with rain." (Hemingway, 1935).

The means by which Hemingway produced the previously mentioned tragic effect and expectations in $A$ Farewell to Arms are derived from the nature of his fictional world that is not much different from the real world. Frederick's affair with Catherine implicitly arouses the premonition of disaster in the fictional world of $A$ Farewell to Arms at the level its narrative structure. Merrill notes that: The novel's pattern is cyclical, as Frederick's fortunes alternately rise and fall. Frederick's memories of the war have been exorcised in his affair with Catherine. But soon the rains come, heralding the end of this idyll (2014). Summer passes into fall, and the lovers' happiness passes with the season. First there is Catherine's premonition about the rain: "I'm afraid of the rain because sometimes I see me dead in it" (Hemingway, 1935). This is followed by Catherine's discovery that 
she is pregnant, Frederick's bout with jaundice, and the cancellation of his leave, and their last night in a hotel, where Catherine feels like a whore (Hemingway, 1935).

War, it seems, the most obvious manifestation of Hemingway's A Farewell to Arms as a tragedy. The bitterness of Frederick at the level of both thoughts and manners reveals Hemingway's tragic vision in the novel as well. Merrill affirms this point about Frederick, who "[...] is blown up while eating a piece of cheese, a dead soldier bleeds all over him as he is transported from the front, he is thrust back into the war only to participate in the nightmarish Caporetto retreat, and finally he is almost executed by his own army. And everyone about him suffers similarly." (Hemingway, 1935). In addition to devices used to indicate the decline of love which leads to readers' tragic expectations, Hemingway uses the device of ill-omens. Nature is the source of such ill-omens. For example, rain is the most obvious omen throughout the novel. It goes hand in hand with the disastrous and tragic events of the novel starting with the marching of the soldiers in the beginning and ending with Catherine's death. According to Baker, "Catherines dying is directly associated with the whole tragic pattern of fatigue and suffering, loneliness, defeat and doom, of which the war is itself the broad social manifestation." (1963) That is, her death suits Hemingway's desired tragic effect - a retelling of Hemingway's worldview of life as a tragedy either in love or in war. Merrill adds, "She [Catherine is not destroyed through her own actions, or Frederick's, or even by the war, Catherine's fate is generalized." (2014).

To sum up, Catherine, per several critics, is a good woman who grew up in a tragic world where her virtue is meaningless. She is qualified to run away with the man she loves and to help him domesticate the world of his wishful dreams. (Note 4) The love affair between Catherine and Frederick is made equal to a valid religious faith per Count Greffi in this novel: "Then too you are in love. Do not forget that is a religious feeling." (Hemingway, 1935). Unlike Aristotelian tragic hero who gets our sympathy because he unknowingly commits a fatal error, Hemingway's hero does not commit a fatal error except that he is a citizen of this world where love is destroyed by war. The novel ends with Hemingway's mystical view about human life as a tragedy simply because the span of human lifetime in this world is temporal by nature. Humans are victimized in time irrespective of the causes. Frederick's nihilistic view of humankind vis-à-vis, the world is the heart of tragedy. In this way, Hegel's the tragic is more highlighted and emphasized in A Farewell to Arms than Aristotle's the tragedy. However, this does not necessarily means Aristotle is ignored; rather, this is a step further in the development of the theory of tragedy. The tragic tension is there in both views of Aristotle and in Hegel.

\section{The Tragic in Mahfouz's The Beginning and the End}

The tragic in Mahfouz is paradoxical in the sense that its hero falls into a tragic lethal end due to his preference of one way of living to another; though both of which are right. Like Hemingway, Mahfouz ignores to an extent some of the classical conventions of tragedy, however, he has his own philosophy of life, as well. Mahfouz's novel is a story of a poor family whose members are both individually and collectively trying to cope with the rigors life and its demands in the aftermath of the death of the head of the family. In his review to this novel, Allen (1988) affirms that the novel is a tragedy as he implicitly heavily pins the blame on the individual as the main cause of the novel's tragic end. However, later we are having Rasheed El-Enany's more objective judgment that is fair enough on the part of the individual as well as the society. Needless to say, there is no some differences between Hemingway's A Farewell to Arms and Mahfouz's The Beginning and the End as far as Hegel's concept of the "tragic" is concerned. Like Hemingway, Mahfouz's tragic hero does not belong to an upper class society; a fact that is opposing to Aristotle's view of the tragic hero. In Mahfouz's novel, the source of the tragic and of what makes this novel a tragedy is the conflict between the past and the present. As we see later, Mahfouz has created an association in the reader's mind between life in the poor family's house and death - such creation is a sort of preparation for the tragic end of the hero as well as his family.

Death seems to Mahfouz as an illusory line and not an end to life. Mahfouz conceives the relationship between time and the individual as a tragic one. This again becomes amply clear towards the end. According to El-Enany, "What is really tragic is the time process in its daily unfolding as it leads up to death" (1993). Mahfouz admits that not every tragedy is of individual; many tragedies are social. In one interview (Note 5) Mahfouz argues that human existence is tragic because it ends in death, but that within this tragic framework there are many artificial tragedies of man's own making, such as ignorance, poverty, etc. This justifies our emphasis on the tragedies of society, because these are tragedies that can be remedied. Again, another tragic element in The Beginning and the End is the lack of fraternity of which Mahfouz himself was deprived - a thing that adds to this novel the autobiographic but tragic color. "For this reason, he tells Ghitani, you can notice that I often portray in my work the relationship between brothers; it is because of my deprivation of it." (qtd. in El-Enany, 1993). 
The Beginning and the End (1949) is set in the Cairo of the mid-1930s, and more particularly in the poor parts of the old suburb of Shubra. The novel is a story of a lower-middle-class family whose head was snatched or died just before the action of the story begins. The source of tragedy in this story is played by the whimsical fate that snatched the father's life; a cause that leads to a serial tragic consequences in form of misfortunes. His death, hence, is the subject-matter of the book as a tragedy. The family comprises a widow, three sons, and a daughter. From Aristotelian point of view, Mahfouz's The Beginning and the End is deemed a tragedy as its action is serious. In this sense, fate is the major character or supernatural force that turns the story into a tragic one. In this regard, El-Enany notes that "The death of the father, however, was only fate's opening skirmish and the narrative maintains an atmosphere of bleakness and a sense of impending doom that leaves the reader in no doubt that more disasters are to come." (1993). It is worthy to mention that the tragic vision of Mahfouz is somehow different from that of Hemingway's in the sense that the former divides tragedy into tragedies either at the individual or at the collective echelons. In this novel, however, the tragedy comes out both at the individual and the collective level as each of the family members has his/her own tragic story. The family suffers first from the demise of its head then poverty — sons have no hope for high education, for instance. Due to poverty, the daughter (Nafisa) is gradually reduced first to a seamstress and then a whore; the eldest son (Hasan) becomes a night-club bouncer and develops into a drug-trafficker, the second son (Husayn) gives up his hope of higher education to become a clerk, and the youngest son (Hasanayn) is persistent to have a great career and struggles against the past of poverty by joining the military academy to become an officer. Hasanayn is the tragic hero, who is never complacent with his past and miserable status quo. However, he relies completely in his struggle and persistence on other members of his family, mainly his sister who turns out to be a whore in order to help him fulfill his dream of overcoming the misery and poverty of the past. Hegel's view of the tragic appears in the novel as clear as the sunlight that the tragic is divided between two goods: the hero's ambition to get rid of the past at any rate and his reliance on his family members to reach his desired end irrespective of the means. The daughter, too, falls in the same trap when she sacrificed her virginity not only for helping her brother but because she is not that beautiful and at the same time she has, like any girl of her age, the stamina for sexual satisfaction. Because she belongs to a poor family, her situation is ill-exploited by a merchant's son who snatches her virginity. In the progress of action, both the individual temperament and the society have played the role of a catalyst to the tragic end of Hasanayn; as well as his sister and eldest brother. However, unlike Husayn; who overcomes his desires by being content with the job of a clerk, the other three characters among who is the hero, are victimized by submissiveness to their individual desires. Mahfouz formula of tragedy of manageable and unmanageable fate is expressed through Husayn, when he tries to convince his brother Hasanayn to accept their poor status and not to be over-ambitious.

To my mind, Hasanayn is a tragic hero because his striving for development of his social status is legal, however, he is shackled by social ill-exploitation of his sister and errors committed by her as well as his eldest brother. The social atmosphere lacks moral standards, not to mention the class structure of the society. Per Hegel's view of tragedy, The Beginning and the End complies with components of tragedy such as serious action, ambitious hero, fatal errors and the tragic end. To El-Enany, "Tragic" is indeed the word he uses to describe his view of life which ends in death for the individual." (1993) It goes without saying that Egypt was totally influenced by Sufis and their view of asceticism through fighting the desires of the lower self in lieu of fighting poverty. The Sufi influence has its own impact on Mahfouz's dualistic view of life as a tragedy.

To sum up, El-Enany affirms that "[...] there too are the roots of the author's tragic sense of life and his profound sadness for the individual, twice crushed by the injustice of society and the less tractable harshness that is at the centre of existence." (1993). The novel shows two-sidedness as far as Mahfouz's tragic vision in The Beginning and the End is concerned. According to El-Enany, "The insistence throughout on Nafisa's physical ugliness and passionate sexuality leave little room for the possibility of blaming her fall on society. Even in a social utopia, she would still be ugly, without a husband, [...]" (1993). To me, Nafisa, too, cannot be blamed for her ugliness and sexual desire because that is a part of her nature as a woman. The same goes with Hasanayn, he feels degraded and he has the full right to rise to an officer's position just like any young man belonging to middle or upper class family. His downfall is a result of the socio-cultural context that never allows a lower class man to enjoy the same rights as men of other classes. Hence, part of the tragedy is the society itself where words speak louder than actions. True, Hasanayn's over-ambition is one of the causes of his tragic downfall, too. In this sense, both the tragic hero and the society are held accountable for his tragic downfall. Due to the social unkindness, Hasanayn has despairingly shown his temperament by saying before jumping into the Nile: "There is something fundamentally wrong with our nature- - I don't know what it is but it has destroyed me." (Mahfouz, 1985). The nature of Mahfouz's tragedy is more complex in the sense that his tragic hero is neither aware of the cause of his downfall nor is he complacent with his tragic end. Oedipus and Sophocles realize finally their errors, 
but Hasanayn. Thus, Mahfouz's The Beginning and the End is a tragedy par excellence. However, this novel is not totally Aristotelian as Mahfouz's vision of tragedy is superadded to Aristotle's and Hegel's as well. Mhafouz adds his flavour to tragedy by presenting the character of Husayn. He is a composite of the Islamist and the socialist models of New Cairo, believing in 'a socialist system which does not conflict with religion, family or morality (Mahfouz, 1985).

\section{Conclusion}

To conclude, both Hemingway and Mahfouz achieve the standards of tragedy as a literary form per the conventions of literary theory as juxtaposed by Aristotle and Hegel in addition to the authors' views of life and tragedy as well. The tragic vision of both writers is mystical in the sense that life is a tragedy as long as characters struggle against the perennial philosophy and past traditions for the sake of satisfying the lower self. Hemingway arbitrarily views life as a tragedy; he never blames his hero and heroine for their as accountable for their tragic end. Mahfouz mystically pins part of the blame on his tragic hero for his tragic end on one hand and on the society on another. No character has been held completely responsible for his tragic end; fate, the individual, and the society are all held accountable for the end of their tragedy. In brief, both writers slightly deviate from Aristotle's theory of tragedy on the part of the tragic hero by going hand in hand with Hegel's definition of tragedy, however, they stick to other Aristotelian basic principles such as seriousness of action throughout the plot of their novels.

\section{Acknowledgments}

The authors are thankful to Dr. Abdulqadir Ali Mohammad Al-Emad, Permanent Faculty Member, Department of English, Faculty of Arts, Thamar University, for his ideas, feedback and advice and guidance during the writing of this paper.

\section{References}

Allen, R. (1988). The Beginning and the End. In N. Mahfouz (Ed.), World Literature Today, 62(3), 504. https://doi.org/10.2307/40144466

Baker, C. (1963). Hemingway, the Writer as Artist (3rd ed.). Princeton, NJ: Princeton UP.

Bloom, H. (1987). Ernest Hemingway's A Farewell to Arms. New York: Chelsea House.

Bushnell, R. W., Deborah, B., \& Claude, C. (2005). A Companion to Tragedy. Grand Rapids: Blackwell Limited.

Cowley, M., \& Donald, W. F. (1990). The Portable Malcolm Cowley. New York: Viking.

Dahiya, B. S. D. (1992). Academic Foundation.

Donaldson, S. (1990). New Essay of a Farewell to Arms. The Companion to Ernest Hemingway. Cambridge: Cambridge UP.

El-Enany, R. (1993). Naguib Mahfouz: The Pursuit of Meaning. London: Routledge.

Hemingway, E. (1935). A Farewell to Arms. Harmondsworth, Mddx. London: Penguin.

Mahfouz, N. (1985). The Beginning and the End (Trans. Ramses Awad. Ed. Mason Rossiter Smith). Cairo: American U in Cairo.

McDonald, M. (2003). The Living Art of Greek Tragedy. Bloomington: Indiana UP. https://doi.org/10.2307/j.ctt1zxxz2q

Memmott, R. L. (2004). The Divine Paradox. Charleston: BookSurge Publishing.

Merrill, R. (1974). Tragic Form in a Farewell to Arms. American Literature, 45(4), 571-579. https://doi.org/10.2307/2924097

Scholes, R., \& Rosemary, S. (1984). Elements of Fiction. Oxford: Oxford UP.

\section{Notes}

Note 1. I am not the first one to say this about Hemingway's depiction of a world void of moral standards. See Robert Merrill: "Tragic Form in A Farewell to Arms." American Literature, 45(4), 573.

Note 2. Source: American Literature, 45(4), 571-579.

Note 3. Ernest Hemingway, "Introduction," A Farewell to Arms (New York, I948), pp. vii-viii. 
Note 4. Scott Donaldson, New essay of A Farewell to Arms (The Companion to Ernest Hemingway, Cambridge UP, 1990).

Note 5. Qtd. in El-Enany (p. 225).

\section{Copyrights}

Copyright for this article is retained by the author, with first publication rights granted to the journal.

This is an open-access article distributed under the terms and conditions of the Creative Commons Attribution license (http://creativecommons.org/licenses/by/4.0/). 